\title{
The Fatty Acid \\ Composition of Sporangiospores and Vegetative Mycelium of Temperature-adapted Fungi in the Order Mucorales
}

\author{
By J. L. SUMNER* AND E. D. MORGAN \\ Biology and Chemistry Departments, University of Keele, Staffordshire, ST55BG
}

(Accepted for publication 27 August 1969)

\begin{abstract}
SUMMARY
The lipid content and fatty acid composition of sporangiospores and vegetative mycelium of mesophilic, thermotolerant and thermophilic fungi in the Mucorales were examined. In each fungus the spores contained less lipid than the vegetative mycelium. The mesophiles accumulated less lipid in spores and mycelium than did thermotolerants and thermophiles. No unusual fatty acids were detected by gas-liquid chromatography in the lipids of spores or mycelium. The fatty acid compositions of spores and vegetative mycelium were qualitatively very similar, but spore lipids were always more highly saturated than mycelial lipids. Lowering growth temperature from 48 to $25^{\circ}$ increased the synthesis of unsaturated fatty acids in the spores and the mycelium of the thermotolerant and thermophilic fungi examined.
\end{abstract}

\section{INTRODUCTION}

There have been several investigations of the fatty acid composition of the lipids of fungal spores, in a number of which a significant proportion of the spore lipid has been shown to comprise 'unusual' fatty acids. In the order Uredinales (rusts) cis-9, I0-epoxyoctadecanoic acid formed up to $40 \%$ of the spore oil (Tulloch, Craig \& Ledingham, I959; Tulloch \& Ledingham, I962). In the order Erysiphales (powdery mildews) the spore lipid of Sphaerotheca humuli was shown to contain $42 \%$ behenic acid, which is rarely found in fungal lipids and then only in trace quantities, while in Erysiphe graminis the spore oil contained $45 \%$ of an unidentified fatty acid, thought to have a branched chain, or cyclic system (Tulloch \& Ledingham, 1960). Sclerotia of Claviceps purpurea contained $34 \%$ ricinoleic acid (12-hydroxystearic acid) but this acid could not be demonstrated in other members of the Hypocreales (Shaw, 1965).

Linoleic acid has been found as a major component of the lipids of spores of widely different groups of fungi. It comprised as much as $60 \%$ of the total fatty acids of sclerotia of Sclerotium rolfsii (Howell \& Fergus, 1964) and $65 \%$ of the spore fatty acids of Penicillium atrovenetum (Van Etten \& Gottlieb, I965). In the fruiting bodies of some Basidiomycetes it accounted for over $70 \%$ of the total fatty acids (Hughes, 1962 ; Bentley, Lavate \& Sweeley, 1964; Shaw, I966a), while spore lipid of the smut Tilletia oetens contained $63 \%$ of it (Tulloch \& Ledingham, I960).

The class Phycomycetes is conspicuously absent from the groups so far examined. The fatty acid composition of the spores of phycomycete fungi was therefore examined

* Present address: Department of Food Science, University of Alberta, Edmonton, Alberta, Canada. 
firstly to determine whether it was similar to that of related mycleium, and secondly to determine whether spore lipids were influenced by the incubation temperature in the same way as were mycelial lipids. There is abundant experimental evidence that microorganisms, in common with other poikilotherms, synthesize increased proportions of unsaturated fatty acids, at the expense of saturated fatty acids, as the incubation temperature is lowered (see Kates, 1964, 1966; and Farrell \& Rose, 1967a, b; for reviews). Curiously, Long \& Williams (I960) found that the spore lipids of the thermophile Bacillus stearothermophilus became more unsaturated as the temperature was raised.

A number of mesophilic, thermotolerant and thermophilic fungi in the order Mucorales were therefore grown at different temperatures, and the lipid content and fatty acid composition of sporangiospores and mycelium determined. The definition of Cooney \& Emerson (1964) that a thermophilic fungus has a maximum temperature for growth at or above $50^{\circ}$ and a minimum temperature for growth at or above $20^{\circ}$, was used to distinguish thermophilic from thermotolerant fungi, the latter having a minimum growth temperature below $20^{\circ}$.

\section{METHODS}

Organisms. The mesophilic fungi used in this investigation were obtained from the Commonwealth Mycological Institute, Kew, England. They were: Mucor mucedo Auct. (IMI I0373I), M. racemosus Fresen. (IMI I03730), M. ramanniaaus Moller. (IMI 35044a) and $M$. hiemalis (+) Wehm. (IMI 2I2I6). The thermotolerant and thermophilic fungi were obtained from Dr H. C. Evans, Biology Department, University of Keele. They were: Rhizopus sp. (thermotolerant), Mucor miehei and $M$. pusillus (thermophilic).

\section{Composition of media, inoculation and incubation}

The culture medium had the following composition (per litre deionized water): $\mathrm{KH}_{2} \mathrm{PO}_{4} \mathrm{I} \mathrm{g}, \mathrm{MgSO}_{4} .7 \mathrm{H}_{2} \mathrm{O} 0.5 \mathrm{~g}$, glucose $20 \mathrm{~g}$, ammonium sulphate $\mathrm{r} \cdot 2 \mathrm{~g}$, sodium succinate $5 \mathrm{~g}$, yeast extract $5 \mathrm{~g}$. Its $\mathrm{pH}$ was adjusted to 6.5 prior to autoclaving. Twenty ml. medium was dispensed into $100 \mathrm{ml}$. Erlenmeyer flasks, and in $50 \mathrm{ml}$. medium containing $2 \%$ agar into $8 \mathrm{oz}$. flat medicine bottles. Inocula were grown on agar slopes for I4 days, mesophiles at $25^{\circ}$ and thermotolerants and thermophiles at $48^{\circ}$.

Two types of cultures were grown, 'mycelial' and 'spore'. 'Mycelial' cultures were grown by inoculating each $100 \mathrm{ml}$. Erlenmeyer flask with $\mathrm{I}$ ml. spore suspension and incubating in still culture for 14 days. Preliminary experiments had shown that under these conditions sporulation was particularly sparse, spores forming less than $0.1 \%$ of the dry weight of the culture. 'Spore' cultures were grown by inoculating each flat medicine bottle with a small inoculum transferred by sterile wire.

All cultures were incubated at the specified temperatures for 14 days and then harvested. Mycelial mats were removed from six replicate Erlenmeyer flasks, washed with deionized water, filtered on a sintered glass disc, dried overnight at $80^{\circ}$ and used as a combined sample. Spores were removed from the surface of the agar slopes by lightly scraping them with a spatula into deionized water. Spore suspensions from a number of replicate flat medicine bottles (usually 25) were pooled, filtered through three layers of cheesecloth and centrifuged. The spore pellet was dried overnight at $80^{\circ}$. 


\section{Extraction and saponification of the fungal lipid}

Dried spores and mycelia were each quickly powdered in a small grinder and the lipid extracted for $8 \mathrm{hr}$ in a Soxhlet apparatus with benzene and ethanol $(594+297 \mathrm{v} / \mathrm{v})$ (Shaw, 1965). The amount of lipid in each sample was calculated by subtracting the weights of material before and after extraction. The lipid was saponified by refluxing with $0.6 \mathrm{M}$-ethanolic $\mathrm{KOH}$ for I hr.

Fatty acid analysis

The mixture of fatty acids was methylated with $\mathrm{BF}_{3} /$ methanol reagent and analysed by gas-liquid chromatography. A $9^{\prime \prime} \times \frac{1}{4}$ " glass column of diethyleneglycolsuccinate ( $5 \%$ ) on chromosorb G (I00 to I 20 mesh) was used in a Pye Model 64 gas chromatograph. The operating temperature was $175^{\circ}$ and the nitrogen carrier gas flow $40 \mathrm{ml} . /$ min. The fatty acid methyl esters were tentatively identified by comparison of retention times with those of authentic standards. Standard fatty acid methyl esters were obtained from Fluka A.G., Bucks, Switzerland and included methyl esters of C I 2 to C 20 saturated acids, as well as the methyl esters of palmitoleic, oleic, linoleic and $\alpha$-linolenic acid. Fatty acid esters were identified completely by combined mass spectrometry and gas-liquid chromatography. The percentages of fatty acid methyl esters were calculated from the peak areas.

\section{RESULTS}

\section{Lipid content of spores and mycelium}

In all the species examined the lipid content of the spores from 'spore' cultures was lower than that of mycelium from 'mycelial' cultures. Also the lipid contents of spores and mycelium of mesophilic fungi were lower than those of thermotolerant and thermophilic fungi. These results are summarized in Tables $I$ and 2.

Table I. Lipid content of spores and mycelium of mesophilic

$$
\text { fungi grown at } 25^{\circ}
$$

Spores and mycelium were harvested from agar-slope cultures and stationary liquid cultures, respectively, after I4 days growth. They were dried and weighed, and the lipid extracted in a Soxhlet apparatus. The amount of lipid present was calculated by weighing each sample before and after extraction.

$\begin{array}{lcc}\text { Organism } & \begin{array}{c}\text { Fungal phase } \\ \text { examined } \\ \text { (spores or mycelium) }\end{array} & \begin{array}{c}\text { Lipid content } \\ \text { (\% of dry } \\ \text { weight) }\end{array} \\ \text { M. mucedo } & \text { Spores } & 3 \cdot 7 \\ \text { M. ramannianus } & \text { Mycelium } & \text { I } 2 \cdot 0 \\ & \text { Spores } & 7 \cdot 6 \\ \text { M. racemosus } & \text { Mycelium } & \text { I } 5 \cdot 2 \\ & \text { Spores } & 4 \cdot \mathrm{I} \\ \text { M. hiemalis } & \text { Mycelium } & 9 \cdot 8 \\ & \text { Spores } & 8 \cdot 4 \\ & \text { Mycelium } & \text { I8. I }\end{array}$

Fatty acid composition of spores and mycelium

No unusual fatty acids were found in the lipids of spores of any of the species examined. Seven fatty acids occurred in measurable amounts: myristic, palmitic, palmitoleic, stearic, oleic, linoleic and linolenic acids; $\alpha$-linolenic acid was absent. The 
triply unsaturated $\mathrm{C}_{\mathrm{I}} 8$ acid was identified as $\gamma$-linolenic acid. This agrees with previous reports that only the $\gamma$-isomer is present in phycomycete fungi (Bernhard \& Albrecht, 1948; Shaw, 1965, 1966a, $b$; White \& Powell, 1966; Tyrrell, 1967 and Sumner, Morgan \& Evans, 1969). These results are summarized in Tables 3 and 4.

The fatty acids of spore and mycelial lipids were very similar both qualitatively and quantitatively, but in each species the spore lipids were more saturated than related mycelial lipids. In these respects the lipids of these mucoraceous fungi are similar to those of Pithomyces chartarum (dematiaceous imperfect fungus) (Hartman, Hawke, Morice \& Shorland, 1960; Hartman, Morice \& Shorland, 1962) in which the spore lipids closely resemble the mycelial lipids though they are more saturated.

\section{Table 2. The effect of incubation temperature on the lipid content of spores and mycelium of thermotolerant and thermophilic fung $i$}

Spore and mycelial cultures were harvested after 14 days growth at either 25 or $48^{\circ}$. After drying and weighing, the lipid was extracted in a Soxhlet apparatus. The lipid content of each sample was calculated by weighing it before and after extraction.

\begin{tabular}{|c|c|c|c|}
\hline Organism* & $\begin{array}{l}\text { Temperature of } \\
\text { incubation }\left(^{\circ}\right)\end{array}$ & $\begin{array}{c}\text { Fungal phase } \\
\text { examined } \\
\text { (spores or mycelium) }\end{array}$ & $\begin{array}{l}\text { Lipid content } \\
\text { (\% of dry } \\
\text { weight) }\end{array}$ \\
\hline Rhizopus sp. & $\begin{array}{l}25 \\
48\end{array}$ & $\begin{array}{l}\text { Spores } \\
\text { Mycelium } \\
\text { Spores } \\
\text { Mycelium }\end{array}$ & $\begin{array}{l}\text { I } 6 \cdot I \\
25 \cdot 7 \\
\text { IO } 4 \\
\text { II } 6\end{array}$ \\
\hline M. miehei & $\begin{array}{r}25 \\
48\end{array}$ & $\begin{array}{l}\text { Spores } \\
\text { Mycelium } \\
\text { Spores } \\
\text { Mycelium }\end{array}$ & $\begin{array}{l}19 \cdot 4 \\
24 \cdot 3 \\
I I \cdot 3 \\
\text { II } \cdot 9\end{array}$ \\
\hline M. pusillus & $\begin{array}{l}25 \\
48\end{array}$ & $\begin{array}{l}\text { Spores } \\
\text { Mycelium } \\
\text { Spores } \\
\text { Mycelium }\end{array}$ & $\begin{array}{l}19 \cdot 3 \\
26 \cdot 2 \\
16 \cdot 1 \\
23 \cdot I\end{array}$ \\
\hline
\end{tabular}

Table 3. Fatty acid composition of spores and mycelium of mesophilic fungi grown at $25^{\circ}$

The lipid of spore and mycelial cultures was saponified, esterified and analysed by gasliquid chromatography. The percentage of each fatty acid was calculated from the peak area. The degree of unsaturation of the lipid was calculated in terms of the number of double bonds/mole from the formula:

$$
\triangle / \text { mole }=\mathrm{I} \cdot 0 \times(\% \text { monoenes }) / 100+2 \cdot 0 \times(\% \text { dienes }) / 100+3 \cdot 0 \times(\% \text { trienes }) / 100 .
$$

\section{Fungal phase mycelium)}

M. mucedo

M. ramannianus

M. racemosus

M. hiemalis

\section{Spores}

Mycelium

\section{Spores} Mycelium

Spores Mycelium

Spores Mycelium
Fatty acids

\begin{tabular}{|c|c|c|c|c|c|c|c|}
\hline $14: 0^{*}$ & I6:0 & I6:I & $18: 0$ & I8:I & $18: 2$ & $18: 3$ & unsaturation \\
\hline $\begin{array}{l}2.5 \\
0.8\end{array}$ & $\begin{array}{l}2 \mathrm{I} \cdot 3 \\
12 \cdot 0\end{array}$ & $\begin{array}{l}3.5 \\
3 \cdot 1\end{array}$ & $\begin{array}{r}\text { I } 2 \cdot 6 \\
9 \cdot 3\end{array}$ & $\begin{array}{l}27 \cdot 2 \\
26 \cdot I\end{array}$ & $\begin{array}{l}21 \cdot 0 \\
25 \cdot 3\end{array}$ & $\begin{array}{l}12 \cdot 0 \\
20 \cdot 2\end{array}$ & $\begin{array}{l}I \cdot 08 \\
I \cdot 40\end{array}$ \\
\hline $\begin{array}{l}4 \cdot 1 \\
I \cdot 6\end{array}$ & $\begin{array}{l}18 \cdot 7 \\
18 \cdot 5\end{array}$ & $\begin{array}{l}3 \cdot 4 \\
2 \cdot 6\end{array}$ & $\begin{array}{l}5 \cdot 5 \\
4 \cdot 4\end{array}$ & $\begin{array}{l}3 I \cdot 2 \\
28 \cdot 0\end{array}$ & $\begin{array}{l}\text { I4. I } \\
\text { I } 3 \cdot 5\end{array}$ & $\begin{array}{l}20.9 \\
30.9\end{array}$ & $\begin{array}{l}1 \cdot 25 \\
1 \cdot 50\end{array}$ \\
\hline $\begin{array}{l}4 \cdot 9 \\
2 \cdot 7\end{array}$ & $\begin{array}{l}21.8 \\
16.9\end{array}$ & $\begin{array}{l}3.8 \\
2.9\end{array}$ & $\begin{array}{l}9 \cdot I \\
4 \cdot 6\end{array}$ & $\begin{array}{l}3 I \cdot 4 \\
36 \cdot 5\end{array}$ & $\begin{array}{l}14.9 \\
16.6\end{array}$ & $\begin{array}{l}14.1 \\
19.4\end{array}$ & $\begin{array}{l}1 \cdot 07 \\
1 \cdot 28\end{array}$ \\
\hline $\begin{array}{l}2 \cdot 0 \\
2 \cdot 4\end{array}$ & $\begin{array}{l}15.0 \\
14.8\end{array}$ & $\begin{array}{l}2 \cdot I \\
3 \cdot I\end{array}$ & $\begin{array}{r}17 \cdot I \\
9 \cdot 7\end{array}$ & $\begin{array}{l}28 \cdot 0 \\
32 \cdot 6\end{array}$ & $\begin{array}{l}17 \cdot 9 \\
18 \cdot 8\end{array}$ & $\begin{array}{l}18 \cdot 0 \\
19 \cdot 2\end{array}$ & $\begin{array}{l}I \cdot 20 \\
I \cdot 29\end{array}$ \\
\hline
\end{tabular}

* The number of carbon atoms: the number of double bonds per molecule. 
The spore lipids were influenced by incubation temperature in the same way as mycelial lipids, being more unsaturated when the fungus had been grown at a lower temperature. The sorts and proportions of fatty acids in spore lipids of mesophiles, thermotolerants, and thermophiles were essentially the same as those in the mycelial lipids; the lipids of mesophiles contained greater proportions of the polyunsaturated acids (linoleic and linolenic acid) and lower proportions of oleic acid, compared with lipids of thermotolerants and thermophiles.

Table 4. Effect of temperature on the fatty acid composition of spores and mycelium of thermotolerant and thermophilic fungi

The lipid extracted from spore and mycelial cultures grown at 25 or $48^{\circ}$ was saponified, esterified and analysed by gas-liquid chromatography. The percentage of each fatty acid was calculated from the peak area. The degree of unsaturation of the lipid was calculated in terms of the number of double bonds/mole:

\begin{tabular}{|c|c|c|c|c|c|c|c|c|c|c|}
\hline \multirow{2}{*}{ Organism } & \multirow{2}{*}{$\begin{array}{l}\text { Tempera- } \\
\text { ture of } \\
\text { incubation } \\
\left(^{\circ}\right)\end{array}$} & \multirow{2}{*}{$\begin{array}{l}\text { Fungal phase } \\
\text { (spores or } \\
\text { mycelium) }\end{array}$} & \multicolumn{7}{|c|}{ Fatty acids } & \multirow{2}{*}{$\begin{array}{c}\text { Degree } \\
\text { of un- } \\
\text { saturation }\end{array}$} \\
\hline & & & 14:0* & $16: 0$ & I6:I & 18:0 & I 8:I & I8:2 & $18: 3$ & \\
\hline Rhizopus sp. & 48 & $\begin{array}{l}\text { Spores } \\
\text { Mycelium } \\
\text { Spores } \\
\text { Mycelium }\end{array}$ & $\begin{array}{r}6 \cdot 0 \\
1.4 \\
5 \cdot 8 \\
\text { Trace }\end{array}$ & $\begin{array}{l}27 \cdot 3 \\
20 \cdot 6 \\
22 \cdot 6 \\
23 \cdot 3\end{array}$ & $\begin{array}{l}2 \cdot 9 \\
2 \cdot 3 \\
2 \cdot 8 \\
3 \cdot 0\end{array}$ & $\begin{array}{r}12 \cdot 1 \\
5 \cdot 2 \\
13 \cdot 8 \\
18 \cdot 6\end{array}$ & $\begin{array}{l}28 \cdot 8 \\
30 \cdot 0 \\
40 \cdot 1 \\
34 \cdot 9\end{array}$ & $\begin{array}{l}10 \cdot 6 \\
28 \cdot 6 \\
11 \cdot 0 \\
21 \cdot 8\end{array}$ & $\begin{array}{r}\text { I } 2 \cdot \text { I } \\
\text { I I } 9 \\
4 \cdot 0 \\
5 \cdot I\end{array}$ & $\begin{array}{l}0.89 \\
I .22 \\
0.77 \\
0.94\end{array}$ \\
\hline M. miehei & $\begin{array}{l}25 \\
48\end{array}$ & $\begin{array}{l}\text { Spores } \\
\text { Mycelium } \\
\text { Spores } \\
\text { Mycelium }\end{array}$ & $\begin{array}{l}5 \cdot 6 \\
I \cdot 6 \\
4 \cdot 0 \\
I \cdot 8\end{array}$ & $\begin{array}{l}24 \cdot 4 \\
22 \cdot 8 \\
26 \cdot 3 \\
27 \cdot 7\end{array}$ & $\begin{array}{l}3 \cdot 1 \\
3 \cdot 0 \\
4 \cdot 8 \\
3 \cdot 0\end{array}$ & $\begin{array}{r}\text { II } 3 \\
4 \cdot 7 \\
9 \cdot 9 \\
6 \cdot 3\end{array}$ & $\begin{array}{l}32 \cdot 6 \\
47 \cdot 8 \\
44 \cdot 0 \\
48 \cdot 0\end{array}$ & $\begin{array}{r}13 \cdot I \\
15 \cdot 8 \\
5 \cdot 9 \\
10 \cdot 3\end{array}$ & $\begin{array}{l}9 \cdot 3 \\
4 \cdot 1 \\
4 \cdot 4 \\
2 \cdot 0\end{array}$ & $\begin{array}{l}0.88 \\
0.95 \\
0.72 \\
0.76\end{array}$ \\
\hline M. pusillus & 48 & $\begin{array}{l}\text { Spores } \\
\text { Mycelium } \\
\text { Spores } \\
\text { Mycelium }\end{array}$ & $\begin{array}{l}I \cdot 0 \\
I \cdot 2 \\
I \cdot 3 \\
I \cdot 5\end{array}$ & $\begin{array}{l}25 \cdot 4 \\
23 \cdot 9 \\
28 \cdot 6 \\
26 \cdot 3\end{array}$ & $\begin{array}{l}3 \cdot 0 \\
3 \cdot 0 \\
2 \cdot 9 \\
3 \cdot 1\end{array}$ & $\begin{array}{l}4 \cdot 8 \\
5 \cdot 6 \\
7 \cdot 1 \\
4 \cdot 3\end{array}$ & $\begin{array}{l}42 \cdot 2 \\
39 \cdot 7 \\
39 \cdot 4 \\
42 \cdot 1\end{array}$ & $\begin{array}{l}19 \cdot 0 \\
20 \cdot 2 \\
17 \cdot 2 \\
19 \cdot 2\end{array}$ & $\begin{array}{l}4 \cdot 5 \\
6 \cdot 3 \\
3 \cdot 4 \\
3 \cdot 6\end{array}$ & $\begin{array}{l}0.97 \\
I .02 \\
0.87 \\
0.93\end{array}$ \\
\hline
\end{tabular}

* See footnote to Table 3 .

\section{DISCUSSION}

The fatty acid compositions of the spores and vegetative mycelium of each organism tested were similar. However, the fact that in each species the spores contained lipid in lower concentration but of a more highly'saturated nature than in the mycelium appears to indicate a modification of the fatty acid synthesizing and fatty acid desaturating systems of sporogenous mycelium. Both enzyme systems have cofactor requirements for acetylcoenzyme A (acetyl CoA), acyl carrier protein (ACP) and the reduced forms of nicotinamide adenine dinucleotide $\left(\mathrm{NADH}_{2}\right)$ or nicotinamide adenine dinucleotide phosphate $\left(\mathrm{NADPH}_{2}\right)$. However, the desaturating enzymes (desaturases) specifically require oxygen, while the synthesizing enzymes (saturases) require carbon dioxide (Mudd \& Stumpf, I96I; James, I963; Stumpf \& James, I963; Nagai \& Bloch, 1966).

A correlation between the need for molecular oxygen in the desaturation reaction and the low dissolved oxygen tensions at high temperatures has been used to explain the increased synthesis of highly saturated lipids in response to increases in temperature (Bloomfield \& Bloch 1960; Meyer \& Bloch, 1963; Harris \& James, 1969). In the present context this explanation seems perfectly acceptable when considering the lipid 
composition of cultures grown at a high and a low temperature; indeed, preliminary experiments have shown that cultures of Mucor pusillus grown at $48^{\circ}$ become oxygen deficient, while those at $25^{\circ}$ do not. However, it does not explain why spore lipids are more saturated than mycelial lipids, even when 'spore' and 'mycelial' cultures are grown at the same temperature.

A number of studies on the biochemical aspects of fungal morphogenesis have indicated that respiratory changes are associated with spore production; increased spore production in Mucor hiemalis and Phycomyces blakesleeanus has been correlated with a reduction in the respiration rate of sporogenous mycelium (Hawker \& Hepden, 1962), while in mitochondria of sporogenous mycelium of Neurospora crassa there is activation of the enzymes of the glyoxylate cycle, and corresponding decrease in activity of enzymes of the Krebs cycle (Turian, 1960; Weiss \& Turian, I966). Also increased activity of proteinase and nuclease enzymes has been demonstrated in spore-producing mycelium of Penicillium griseofulvum (Morton, Dickerson \& England, 1960). Accumulation of only small concentrations of lipid, but of a highly saturated nature, may therefore be caused by a reduction in the activities of synthetase and desaturase enzymes resulting from a check in the respiration rate of sporogenous mycelium. A depression of respiratory rate would effectively reduce the level of a number of respiratory metabolites, e.g. acetyl $\mathrm{CoA}, \mathrm{NADH}_{2}, \mathrm{NADPH}_{2}$, carbon dioxide, which are also substrates for fatty acid biosynthesis.

This work was supported by a research fellowship from Jeyes Group Limited, for which we are grateful. We are indebted to Dr C. Hitchcock, Dr W. Kelly and Professor A. J. James of the Unilever Research Laboratory, Sharnbrook, Beds. for mass spectral determination of the fatty acid esters, to $\mathrm{Mr} \mathrm{J}$. C. Wickens of Roche Products, Welwyn Garden City, Herts. for kindly providing the mass spectrum of authentic methyl- $\gamma$-linolenate, and to the Science Research Council for a grant to purchase gas chromatography equipment.

\section{REFERENCES}

Bentley, R., Lavate, W. V. \& Sweeley, C. C. (1964). Lipid components of two basidiomycetes, Calvatia gigantea \& Clitocybe illudens. Comp. Biochem. Physiol. II, 263.

Bernhard, K. \& Albrecht, H. (1948). Die Lipide aus Phycomyces blakesleeanus. Helv. chim. Acta 31, 977.

BLoOMfield, D. K. \& BLOCH, K. (1960). The formation of $\triangle^{9}$-unsaturated fatty acids. J. biol. Chem. 235, 337 .

Cooney, D. G. \& Emerson, R. (1964). Thermophilic Fungi. London: W. H. Freeman and Co.

VAN EtTen, J. L. \& Gorthieb, D. (1965). Biochemical changes during the growth of fungi. II. Ergosterol \& fatty acids in Penicillium atrovenetum. J. Bact. 89, 409.

FARrell, J. \& Rose, A. H. (1967a). Temperature relationships among micro-organisms. In Thermobiology. Ed. by A. H. Rose, p. 147. New York: Academic Press.

FARrell, J. \& RoSe, A. H. (1967b). Temperature effects on micro-organisms. A. Rev. Microbiol. 21, IOI.

Harris, P. \& James, A. T. (1969). The effect of low temperatures on fatty acid biosynthesis in plants. Biochem. J. I12, 325.

Hartiman, L., Hawke, J. C., Morice, I. M. \& Shorland, F. B. (I960). The component fatty acids of Sporidesmium bakeri lipids. Biochem. J. 75, 274.

Hartman, L., Morice, I. M. \& Shorland, F. B. (I962). Further studies of lipids of Pithomyces chartarum (Sporidesmium bakeri) and related fungi. Biochem. J. 82, 76. 
HaWkeR, L. E. \& HePden, P. M. (I962). Sporulation in Rhizopus sexualis and some other fungi following a period of intense respiration. Ann. Bot. N.S. 26, 619 .

Howell, D. M. \& Fergus, C. L. (1964). The component fatty acids found in sclerotia of Sclerotium rolfsii. Can. J. Microbiol. 10, 616.

Hughes, D. H. (1962). Preliminary characterisation of the lipid constituents of the cultivated mushroom Agaricus campestris. Mushr. Sci. 5, 540 .

JAMES, A. T. (1963). The biosynthesis of long-chain saturated and unsaturated fatty acids in isolated plant leaves. Biochim. biophys. Acta 70, 9.

Kates, M. (1964). Bacterial lipids. In Advances in Lipid Research, Ed. by R. Paoletti and D. Kritchevsky vol. 2, p. 17. New York: Academic Press.

Kates, M. (I966). Biosynthesis of lipids in micro-organisms. A. Rev. Microbiol. 20, I3.

LoNG, S. K. \& Williams, O. B. (1960). Lipids of Bacillus stearothermophilus. J. Bact. 79, 629.

MEYER, F. \& BLOCH, K. (1963). Effect of temperature on the enzymatic synthesis of unsaturated fatty acids in Torulopsis utilis. Biochim. biophys. Acta 77, 671.

Morton, A. G., Dickerson, A. G. F. \& England, D. J. E. (1960). Changes in enzyme activity of fungi during starvation. J. exp. Bot. II, II 6.

MudD, J. B. \& STUMPF, P. K. (I96I). Fat metabolism in plants. XIV. Factors affecting the synthesis of oleic acid by particulate preparations from Avocado mesocarp. J. biol. Chem. 236, 2602.

NAGAI, J. \& BlOCH, K. (1966). Enzymatic desaturation of stearyl acyl carrier protein. J. biol. Chem. 24I, 1925.

SHAw, R. (I965). The occurrence of $\gamma$-linolenic acid in fungi. Biochim. biophys. Acta 98, 230.

SHAw, R. (1966a). Fatty acids of fruiting bodies of basidiomycetes. Nature, Lond. 213, 86.

SHAw, R. (I966 $b$ ). The fatty acids of phycomycete fungi, and the significance of the $\gamma$-linolenic acid component. Comp. Biochem. Physiol. 18, 325.

STUMPF, P. K. \& JAMES, A. T. (1963). The biosynthesis of long-chain fatty acids by lettuce chloroplast preparations. Biochim. biophys. Acta 70, 19.

Sumner, J. L., Morgan, E. D. \& Evans, H. C. (1969). The effect of growth temperature on the fatty acid composition of fungi in the order Mucorales. Can. J. Microbiol. (in Press).

Tulloch, A. P. \& Ledingham, G. A. (I960). The component fatty acids of oils found in spores of plant rusts and other fungi. Can. J. Microbiol. 6, 425.

Tulloch, A. P. \& Ledingham, G. A. (1962). The component fatty acids of oils found in spores of plant rusts and other fungi. Part II. Can. J. Microbiol. 8, 379.

Tulloch, A. P., Craig, B. M. \& Ledingham, G. A. (1959). The oil of wheat stem rust uredospores. II. The isolation of cis-9, I0-epoxyoctadecanoic acid, and the fatty acid composition of the oil. Can. J. Microbiol. 5, 485.

TURIAN, G. (1960). Deficiencies in oxidative metabolism and sexual differentiation of Allomyces \& Neurospora. Activity of a diphosphopyridine nucleotide (DPN)-lactic dehydrogenase in Allomyces. Pathologia Microbiol. 23, 687.

TYrReLL, D. (1967). The fatty acid composition of 17 Entomophthora isolates. Can. J. Microbiol. r3, 755 .

Weiss, B. \& TuRIAN, G. (1966). A study of conidiation in Neurospora crassa. J. gen. Microbiol. 44, 407.

White, H. B. \& Powell, S. S. (1966). Fatty acid distribution in mycelial lipid of Choanephora cucurbitarum. Biochim. biophys. Acta rr6, 388. 